\title{
A INCLUSÃO DE ALUNOS COM DEFICIÊNCIA MENTAL E SÍNDROME DE DOWN NA REDE REGULAR DE ENSINO
}

\author{
Elaine Aparecida Saraiva Batista. \\ saraivabatista@hotmail.com
}

Linha de pesquisa: Prática pedagógicas

\section{Resumo:}

Este estudo se voltou para a análise das práticas pedagógicas desenvolvidas no processo de ensino-aprendizagem de alunos com necessidades educacionais especiais decorrentes da deficiência mental e Síndrome de Down incluídos em classes comuns da rede pública regular de ensino. Para elaboração do mesmo foram formulados questionários sobre os temas e montada uma entrevista direcionada a pais, professores, itinerantes e coordenadoras do Projeto de Inclusão da rede municipal de ensino do município de Naviraí, MS. A idade dos alunos foi entre 6 a 15 anos. O tema central tratou de como os profissionais da educação têm lidado com o tema "inclusão". E como pais e responsáveis lidam com alunos com deficiência. De acordo com os depoimentos de professores, itinerantes e familiares a respeito do processo de inclusão na teoria tudo é satisfatório, porém na prática está deixando a desejar. Pois para professores a pouco retorno sobre como trabalhar com esses alunos e para pais o sistema de saúde é falho e demorado. O estudo revelou não só as deficiências e problemas, mas acima de tudo a complexidade do processo de inclusão vivido pelas escolas, particularmente no âmbito das práticas curriculares dirigidas para o processo de ensino-aprendizagem dos alunos. Enfim, a grande importância da inclusão se dá pela necessidade da criança de vivenciar experiências que permita seu desenvolvimento, respeitando suas deficiências e explorando suas habilidades.

Palavras chave: Inclusão Escolar, Síndrome de Down, rede municipal. 